\title{
Saturation Levels by Bases and Time of Incubation in the Development and Growth of Ornamental Sunflower
}

\author{
Edna Maria Bonfim-Silva*, Camila Thaiana Rueda da Silva, Priscila Barros Feitosa, \\ Tássia Maira Greco, Ana Paula Alves Barreto Damasceno, Rackel Danielly de Souza Alves
}

Department of Agricultural and Environmental Engineering, Institute of Agricultural Sciences and Technology, Federal University of Mato Grosso, Rondonópolis, Brazil

Email: *embonfim@hotmail.com

How to cite this paper: Bonfim-Silva, E.M., da Silva, C.T.R., Feitosa, P.B., Greco, T.M., Damasceno, A.P.A.B. and de Souza Alves, R.D. (2019) Saturation Levels by Bases and Time of Incubation in the Development and Growth of Ornamental Sunflower. Agricultural Sciences, 10, 852-869. https://doi.org/10.4236/as.2019.107065

Received: May 29, 2019

Accepted: July 6, 2019

Published: July 9, 2019

Copyright $\odot 2019$ by author(s) and Scientific Research Publishing Inc. This work is licensed under the Creative Commons Attribution International License (CC BY 4.0).

http://creativecommons.org/licenses/by/4.0/

(c) (i) Open Access

\begin{abstract}
Floriculture is a promising segment of Brazilian agriculture. The ornamental sunflower (Helianthus annuus L. cv. Folded Sungold), also known as dwarf sunflower, in addition to being used in gardens can be marketed as cut flower or vase. The sunflower represents a great alternative for small producers because it requires little space, has easy handling and short cycle, besides providing greater economic return. In this context, we aimed to evaluate the development of this culture submitted to different levels of saturation per base, combined with the incubation time of the limestone. The experiment was carried out in a greenhouse at the Federal University of Mato Grosso-University Campus of Rondonópolis. A randomized block design with factorial scheme $6 \times 2$ was used, with six levels of saturation per base: $0,20 \%, 40 \%$, $60 \%, 80 \%, 100 \%$; and two incubation times: 0 and 30 days, resulting in 12 treatments with four replicates, totaling 48 experimental units. Each plot consisted of a plastic polyethylene vessel with a capacity of $1.2 \mathrm{dm}^{-3}$. The following variables were analyzed: Height of the floral stem; number of leaves, diameter of chapters; root volume; fresh mass of leaves; fresh mass of floral stems; fresh mass of chapters; fresh root mass and chlorophyll index (SPAD). Data were submitted to analysis of variance by the test $\mathrm{F}$ at $5 \%$ probability of error. The qualitative factors were submitted to the Tukey test and quantitative factors to the regression test, both with a $5 \%$ probability of error. Basal saturation levels of $80 \%$ and $100 \%$, in the treatment with incubated soil, provided higher quality of inflorescence for commercialization purposes.
\end{abstract}

\section{Keywords}

Cut Flower, Liming, Agronomic Performance 


\section{Introduction}

Worldwide, the floriculture occupies an area estimated at 190 thousand hectares and moves values close to $\$ 60$ billion per year. The segment of cut flowers is the most expressive, followed by that of live plants, bulbs and foliage [1]. In general, Brazil's participation in the international market occurs through the export of propagating materials such as bulbs, tubers, rhizomes and seedlings [2] [3].

The sunflower is a crop with high ornamental potential and can be an alternative to floriculture because of its wide adaptability to different edaphoclimatic conditions, presenting tolerance to temperature variations, which allows its adaptation to any region of the country. In addition, it presents agronomic desirable characteristics, such as short cycle, rusticity and resistance to drought [4].

The sunflower (Helianthus annuus L.), belonging to the order Asterales, family Asteracea, is an alternative of great potential for commercialization of cut flower or pot, and the characteristics that add commercial value are: inflorescence diameter and stem length [5].

Cerrado soils are characterized by high acidity, aluminum toxicity and poor nutrient content essential to most plants [6]. Sunflower crop is very sensitive to soil acidity [7], which is recognized as one of the main factors leading to low crop productivity in the country [8]. For the correction of soil acidity, one of the most used methods is that of base saturation, which needs to be defined considering the requirements of each species [9].

The objective of this study was to evaluate the effect of the soil acidity correction by the saturation levels by base combined with the incubation time of the limestone, thus evaluating the best response to dwarf sunflower (Helianthus annuus L. cv. Dobrado Sungold).

\section{Material and Methods}

The research was conducted in a greenhouse belonging to the Federal University of Mato Grosso, Rondonópolis Campus, located geographically in the latitude $16^{\circ} 27^{\prime} 49^{\prime \prime}$, longitude $55^{\circ} 34^{\prime} 47^{\prime \prime} \mathrm{W}$, and altitude of $284 \mathrm{~m}$. The climate of the region according to the classification of Köppen is of type Aw, tropical, characterized by the dry season in the winter [10].

The experimental design was completely randomized, in a $6 \times 2$ factorial scheme, with 12 treatments in four replicates, obtaining a total of 48 experimental plots. The treatments consisted of two soil incubation times with limestone (0 and 30 days) and six soil saturation levels (0,20\%, 40\%,60\%, 80\% and 100\%). Each experimental plot consisted of a plastic polyethylene vessel, with a capacity of $1.2 \mathrm{dm}^{-3}$.

Soil from the collection area was classified as Red Latosol Dystrophic [11], of clay d texture, occupied with vegetation native to the Cerrado.

The soil was collected, covering the layer of $0.0-0.20 \mathrm{~m}$. After the collection, the soil was sieved in a $4 \mathrm{~mm}$ mesh for homogenization, weighed and transferred to reserve containers. 
Then, a composite sample of the soil was sent to carry out the chemical analysis, expressed in Table 1.

Calculations for soil acidity correction were performed using the base saturation method $\left(\mathrm{NC}=\left[\left(\mathrm{V}_{2}-\mathrm{V}_{1}\right) \times \mathrm{CTC}\right] / 100\right)$ obtained in soil chemical analysis. To increase the V\% corresponding to the treatments of $20 \%, 40 \%, 60 \%, 80 \%$ and $100 \%$ of the saturation by bases, dolomitic limestone $\left(\mathrm{CaCO}_{3} \cdot \mathrm{MgCO}_{3}\right)$ with $86 \%$ PRNT in the amounts of $0.346 \mathrm{~g} \cdot \mathrm{dm}^{-3} ; 1.09 \mathrm{~g} \cdot \mathrm{dm}^{-3} ; 1.8 \mathrm{~g} \cdot \mathrm{dm}^{-3} ; 2.6 \mathrm{~g} \cdot \mathrm{dm}^{-3} ; 3.3$ $\mathrm{g} \cdot \mathrm{dm}^{-3}$; respectively.

After 30 days of planting, the limestone was incorporated to the soil and then water was added for raising to the level of $80 \%$ of the maximum soil water retention capacity or field capacity (CC), allowing the reaction of the soil. limestone. This process was carried out to constitute the treatment of 30 days of incubation. For the 0 day incubation treatment, liming was performed together with fertilization on the day of planting.

The variety used in the study was the ornamental sunflower: Helianthus annuus L. cv. Folded Sungold.

A germination test (Figure 1(a)) was performed to verify seed viability. Afterwards, the sowing was done directly in the pot, with three seeds per pot, together with the application of fertilization $(\mathrm{KCl}+\mathrm{SS})$. After germination, thinning (Figure 1(b)) was done in order to maintain one plant per pot.

At the time of planting, soil samples were collected in each experimental unit for $\mathrm{pH}$ measurement [12]. The procedure was repeated in each cut of the plants (Figure 2 and Figure 3 ) in order to verify if there was alteration after the cultivation.

Table 1. Chemical analysis of Dystrophic Red Latosol (layer $0-0.2 \mathrm{~m}$ ) in an area under Cerrado vegetation. Rondonópolis, 2018.

\begin{tabular}{|c|c|c|c|c|c|c|c|c|c|c|c|}
\hline $\mathrm{pH}$ & $\mathrm{P}$ & $\mathrm{K}$ & $\mathrm{S}$ & $\mathrm{Ca}$ & $\mathrm{Mg}$ & $\mathrm{Al}$ & $\mathrm{H}+\mathrm{Al}$ & M.O & CTC & $\mathrm{V}$ & $\mathrm{m}$ \\
\hline $\mathrm{CaCl}_{2}$ & & $\mathrm{mg} \cdot \mathrm{dm}^{-3}$ & & & \multicolumn{2}{|c|}{$\mathrm{cmol}_{c} \cdot \mathrm{dm}^{-3}$} & & $\mathrm{~g} \cdot \mathrm{Kg}^{-1}$ & ------ & \multicolumn{2}{|c|}{$\%$} \\
\hline 4.00 & 1.30 & 33.00 & 2.00 & 0.40 & 0.20 & 1.10 & 5.70 & 21.20 & 6.40 & 10.70 & 61.80 \\
\hline
\end{tabular}

$\mathrm{P}=$ Phosphorus $\mathrm{K}=$ Potassium; $\mathrm{S}=$ Sulfur; $\mathrm{Ca}=$ Calcium; $\mathrm{Mg}=$ Magnesium; $\mathrm{Al}=$ Aluminum $\mathbf{M} . \mathrm{O}=\mathrm{Or}-$ ganic matter; $\mathrm{CTC}=$ Cation Exchange Capacity; $\mathrm{V}=$ Basis Saturation; $\mathrm{m}=$ Aluminum saturation .
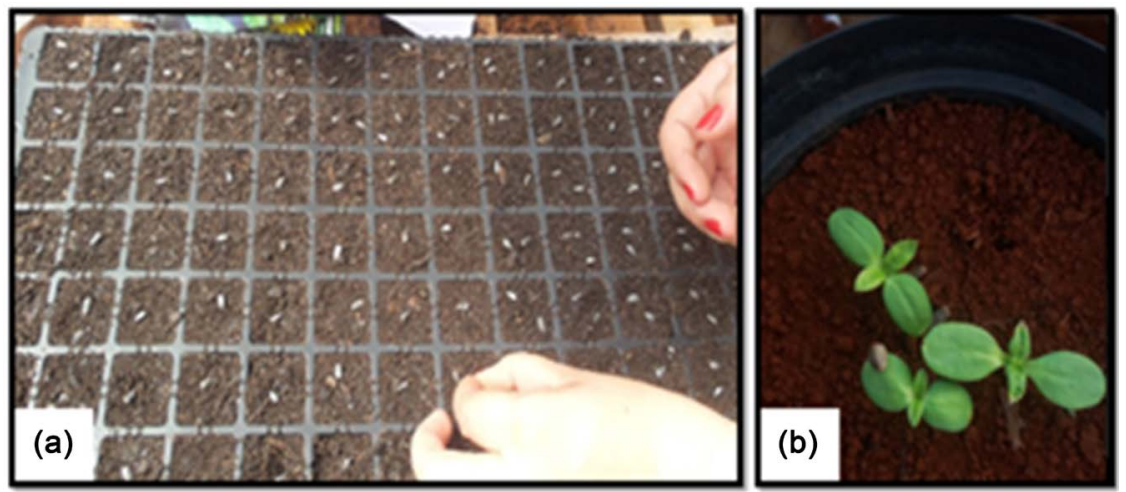

Figure 1. Germination tray (a) and planting of seedlings of Helianthus annuus L. cv. Folded Sungold (b). 


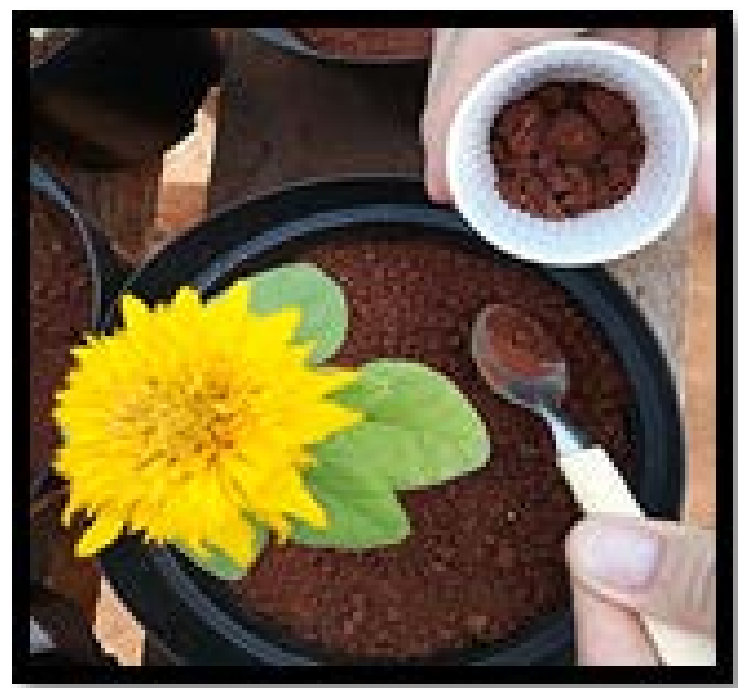

Figure 2. Soil collection for $\mathrm{pH}$ verification at the time of harvest of Helianthus annuus $\mathrm{L}$. cv. Folded Sungold.
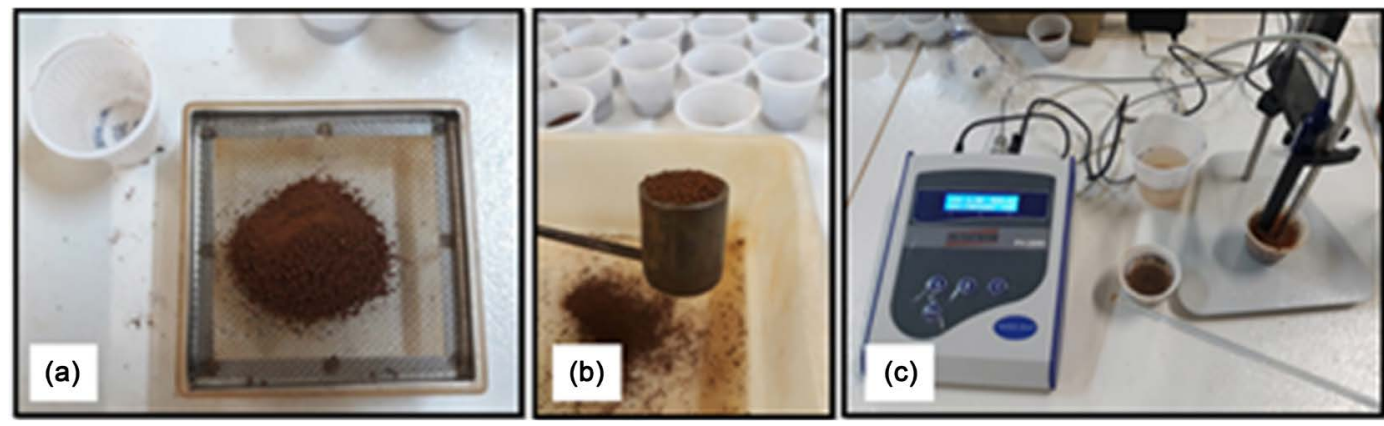

Figure 3. Soil screening (a) and dosage (b) to perform soil $\mathrm{pH}$ analysis in $\mathrm{CaCl}_{2}$ solution (c).

All treatments received phosphate fertilization $\left(\mathrm{P}_{2} \mathrm{O}_{5}\right)$ at the recommendation of $444.4 \mathrm{mg} \cdot \mathrm{dm}^{-3}$, potassium $\left(\mathrm{K}_{2} \mathrm{O}\right)$ of $133.3 \mathrm{mg} \cdot \mathrm{dm}^{-3}$ at the time of planting, and nitrogen (N) of $11.1 \mathrm{mg} \cdot \mathrm{dm}^{-3}$, split at 14 and 28 days after sowing (DAS) [13] (Figure 4). The sources of nutrients were simple superphosphate (SS), potassium chloride $(\mathrm{KCl})$ and urea respectively.

Irrigation management was performed by the gravimetric method, following the methodology of the reference [14] for the determination of the field capacity or maximum water retention capacity of the soil. The water was manually replenished once daily and by surface medium. At each replenishment, the vessels were weighed and then received the necessary water to maintain the level of $60 \%$ of the field capacity.

At 15, 30, 45 and 60 days after sowing (DAS), the following variables were analyzed: SPAD index; flower stem height; stem diameter; button diameter; floral frame and number of sheets. At 60 DAS were also evaluated other variables, being: fresh and dry mass of shoot (stem and leaves) and chapters; root volume and dry root mass.

The chlorophyll index (SPAD index) was measured using the Minolta 502 Portable Meter (Figure 5(a)). To measure the height of the floral stem (Figure 5(b)), 


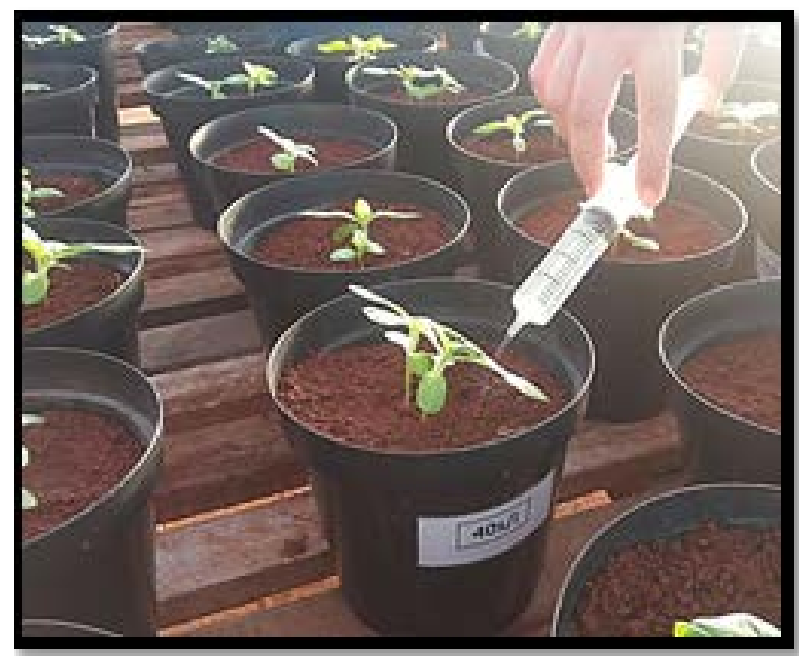

Figure 4. Urea application in the experimental plots.
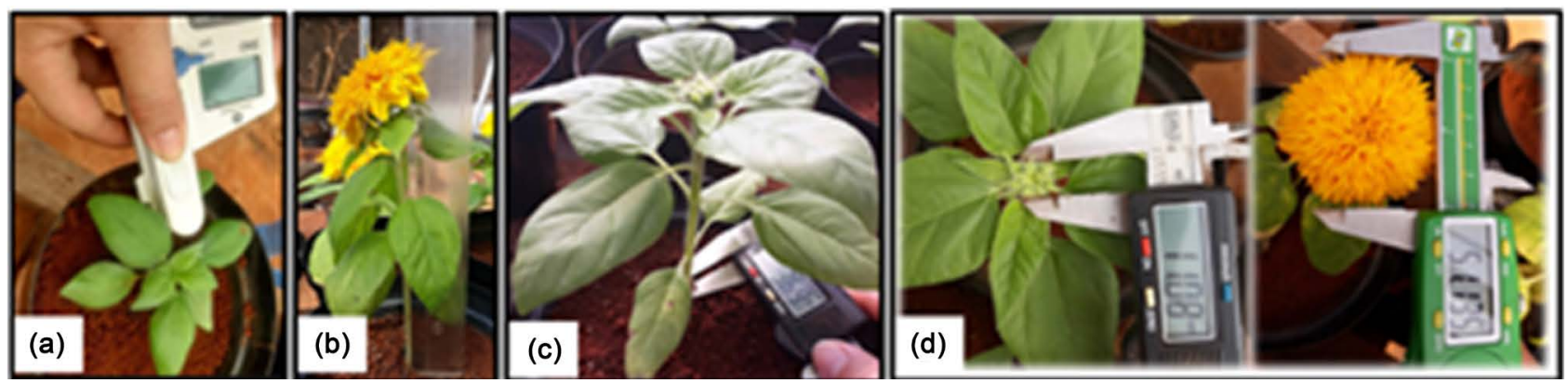

Figure 5. SPAD index (a), height (b), stem diameter (c) and floral and button diameter (d) of Helianthus annuus L. cv. Folded Sungold at 15, 30, 45 and 60 DAS.

a graduated ruler was used, measuring from the base of the soil to the apex of the floral bud. The floral stem diameters (Figure 5(c)) and the chapters (Figure 5(d)) were measured using a digital caliper. For floral stem was measured the diameter $5 \mathrm{~cm}$ above the ground, and, for chapters from one end to another. The number of leaves was obtained by manual counting in each plot.

The fresh shoot mass and chapters consisted of cutting for separation between the leaf stem and the chapters (Figure 6(a)), followed by weighing in semi-analytical balance. To obtain the root volume, the soil was removed from the pots in order to extract the entire root. The root system was then washed in running water for the removal of all impurities (Figure 6(b)). The root system was separated from the rest of the plant and deposited in a graduated cylinder containing a known volume of water. The root volume is attributed to the difference in initial and post-root water volume in the beaker.

The results were submitted to analysis of variance by the $\mathrm{F}$ test at $5 \%$ probability. The qualitative factors (days of incubation) were submitted to the Tukey test and the quantitative factors (base saturation levels) were submitted to the regression test, both at 5\% probability. A statistical program SISVAR version 5.6 was used [15]. 


\section{Results and Discussion}

\subsection{Soil pH at Planting and Harvest Time}

For the treatment where the soil was incubated with limestone for 30 days (Figure 7), the $\mathrm{pH}$ at the time of planting was: 4.2; 4.6; 5.0; 5.4; 5.8 and 5.9 for the saturation levels of $0,20 \%, 40 \%, 60 \%, 80 \%$ and $100 \%$, respectively. These values varied little when evaluated at the time of harvesting/cutting.

For treatment without soil incubation (Figure 8), in which limestone was incorporated on the same day of fertilization and planting, the $\mathrm{pH}$ at planting time was: $4.3 ; 4.3 ; 4.6 ; 5.0 ; 5.0 ; 5.6$ for the saturation levels of $0,20 \%, 40 \%, 60 \%, 80 \%$ and $100 \%$, respectively. The values relatively lower than those of the incubation treatment point out the need to adopt a window time between the incorporation of the limestone and the fertilization procedures so that the limestone reacts and

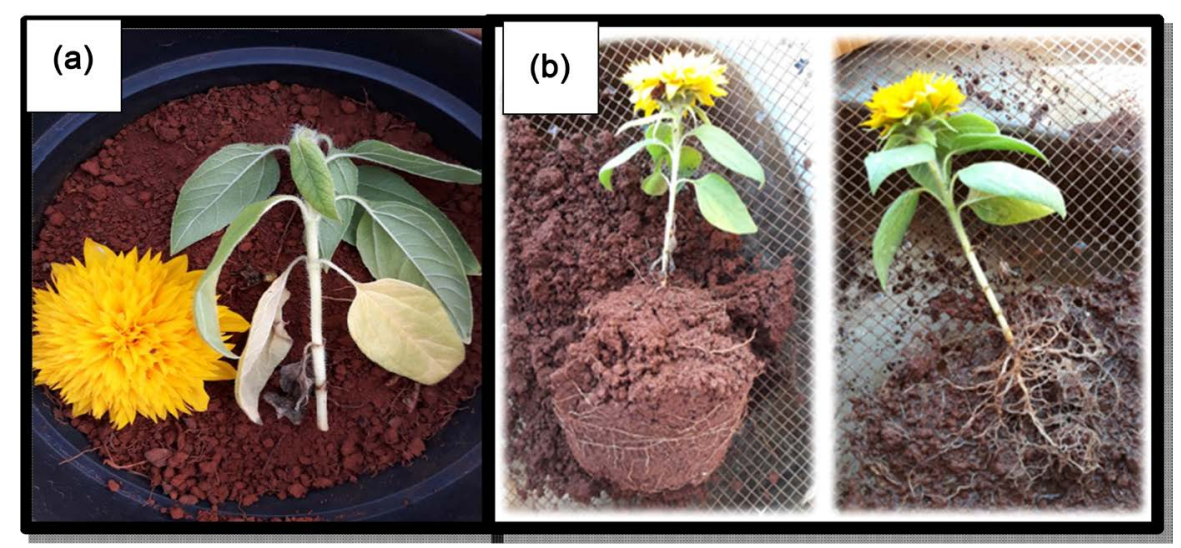

Figure 6. (a) Cut of the aerial part and floral chapters of Helianthus annuus L. cv. Folded Sungold; (b) Procedure for root extraction of Helianthus annuus L. cv. Folded Sungold.

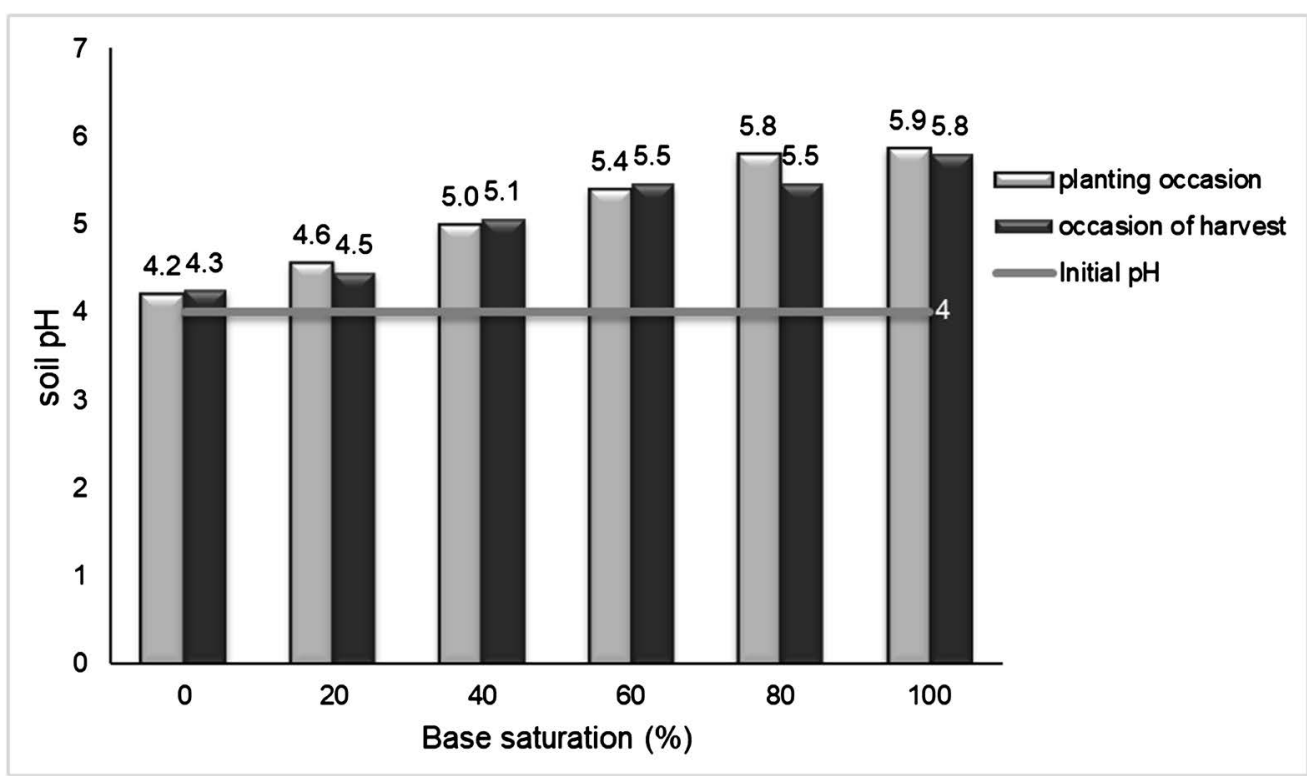

Figure 7. Soil $\mathrm{pH}$, in the treatment with incubated soil, at the time of planting and harvesting of $\mathrm{He}^{-}$ lianthus annuus L. cv. Folded Sungold. 


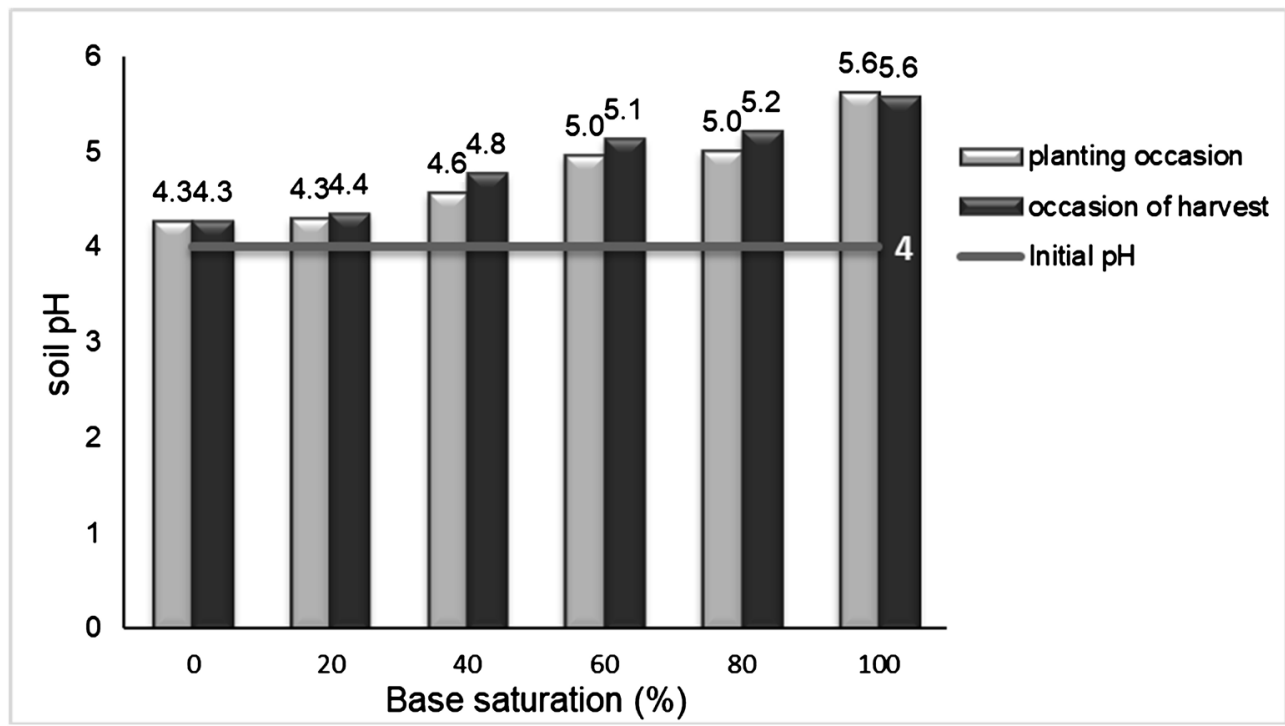

Figure 8. Soil $\mathrm{pH}$, in the treatment no incubation, at the time of planting and harvesting of $\mathrm{He}$ lianthus annuus L. cv. Folded Sungold.

promotes conditions favorable to the absorption of nutrients.

According to reference [16], the ideal $\mathrm{pH}$ range for the best use of nutrients by crops varies between 6.0 and 7.0. The practice of incorporating limestone and then performing fertilization is inadequate and may lead to the formation of certain compounds such as calcium phosphate, and thus, in addition to not correcting the acidity will not provide essential nutrients.

\subsection{Plants Height}

For the plant height at 15, 30, 45 and 60 DAS, there was an isolated effect only for the saturation levels per base, adjusting to a linear model (Figure 9). The maximum plant height was observed at baseline saturation of $100 \%$, and the $\mathrm{pH}$ was in the mean of 5.85 and 5.60; for treatment of 0 and 30 days, respectively.

At the time of the first 15 DAS evaluation, a photo was taken to visually evaluate plant growth at $0 \%, 20 \%, 40 \%, 60 \%, 80 \%$ and $100 \%$ base saturation rates within each soil condition: incubated (Figure 10(a)) and no incubation (Figure 10(b)).

The results of this experiment are in agreement with the reference [7], that working with the sunflower cultivar IAC-Anhandy in the municipality of Mococa, SP, verified that the heights of the sunflower plants are influenced by the soil acidity and the reference [17], evaluating the tolerance of sunflower to different concentrations of aluminum, found that the increase of aluminum concentrations influenced the reduction of plant height. These studies show the sensitivity of sunflower to soil acidity and corroborate with the results of previous studies [18] [19] [20].

For the days of limestone incorporation there were no significant results for plant height, this result can be justified by the low $\mathrm{pH}$ variation between treatments of 0 and 30 days, thus causing an insignificant oscillation in soil acidity. 

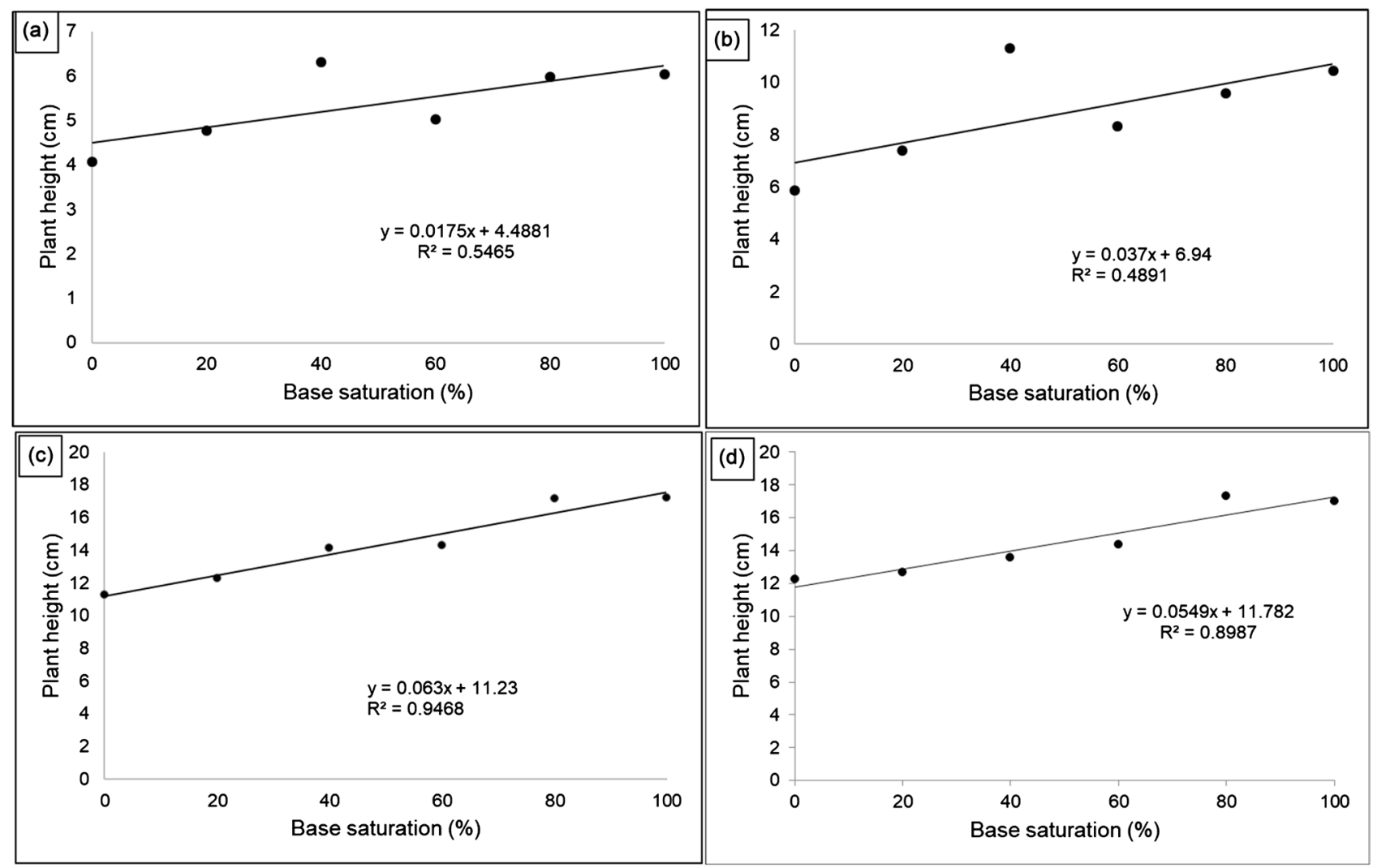

Figure 9. Plant height of Helianthus annuus L. cv. Folded Sungold at 15 (a), 30 (b), 45 (c) and 60 (d) DAS, with isolated effect of Base Saturation.
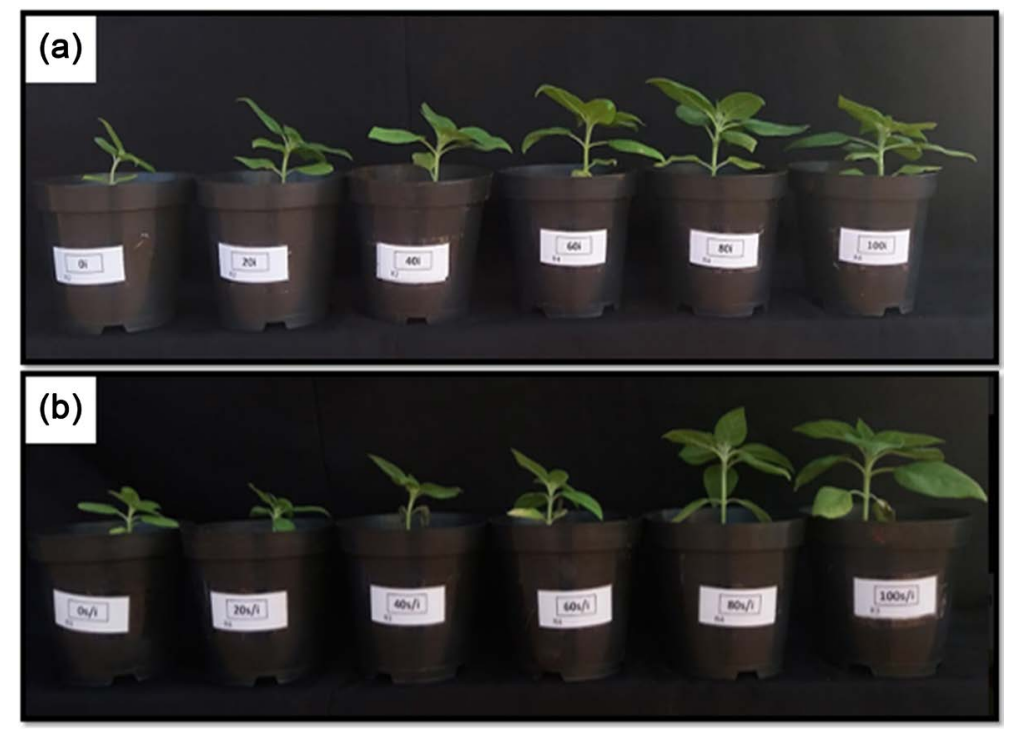

Figure 10. Plant heightof Helianthus annuus L. cv. Folded Sungold at the doses of 0, 20\%, 40\%, 60\%, 80\% and $100 \%$ of base saturation in soil condition: incubated (a) and no incubated (b).

\subsection{Number of Leaves}

For the number of leaves, interaction between base saturation levels and incubation time at 15 DAS was identified (Table 2). At all levels of base saturation, 
treatment with 30 days of incubation showed greater foliage development, differing significantly from treatment no incubation.

The incubated treatment responded linearly and the no incubation had a quadratic response (Figure 11(a) and Figure 11(b), respectively). In the evaluation period, it was verified that in the treatment no incubation the leaf development was unequipped between the levels of $20 \%$ to $60 \%$ of base saturation. This result reflects the effect of the incorporation of limestone on the same day fertilization and planting was carried out, which may have led to a lower nutrient utilization and, consequently, led to irregular foliage development. In addition, the count did not distinguish large leaves and small leaves.

For saturation of $100 \%$ in the incubated treatment and no incubation, the $\mathrm{pH}$ was in the range of 5.85 and 5.6, respectively, being these the highest values found during the tests. At 30 DAS an isolated effect was achieved for the saturation levels by base and incubation time (Figure 12(a) and Figure 12(b)), as well as at 45 DAS (Figure 12(c) and Figure 12(d)). It was verified at 30 and 45 DAS that the treatments incubated (30 days) obtained the best results, this fact is explained by the time that the limestone had to react chemically with the soil, thus conforming with the liming recommendation bulletins used in the routine agricultural.

Table 2. Number of leaves interaction and incubation time at 15 DAS. Averages followed by the same letter do not differ in vertical.

\begin{tabular}{ccccccc}
\hline \multirow{2}{*}{ Days of Incubation } & \multicolumn{7}{c}{ Base Saturation (\%) } \\
\cline { 2 - 6 } & 0 & 20 & 40 & 60 & 80 & 100 \\
\hline 0 & $7.0 \mathrm{a}$ & $7.0 \mathrm{a}$ & $6.75 \mathrm{a}$ & $7.0 \mathrm{~b}$ & $8.5 \mathrm{~b}$ & $8.75 \mathrm{~b}$ \\
30 & $8.25 \mathrm{a}$ & $8.0 \mathrm{a}$ & $8.25 \mathrm{a}$ & $10.0 \mathrm{a}$ & $10.5 \mathrm{a}$ & $10.75 \mathrm{a}$ \\
$\mathrm{CV}(\%)$ & 13.72 & & & & & \\
\hline
\end{tabular}

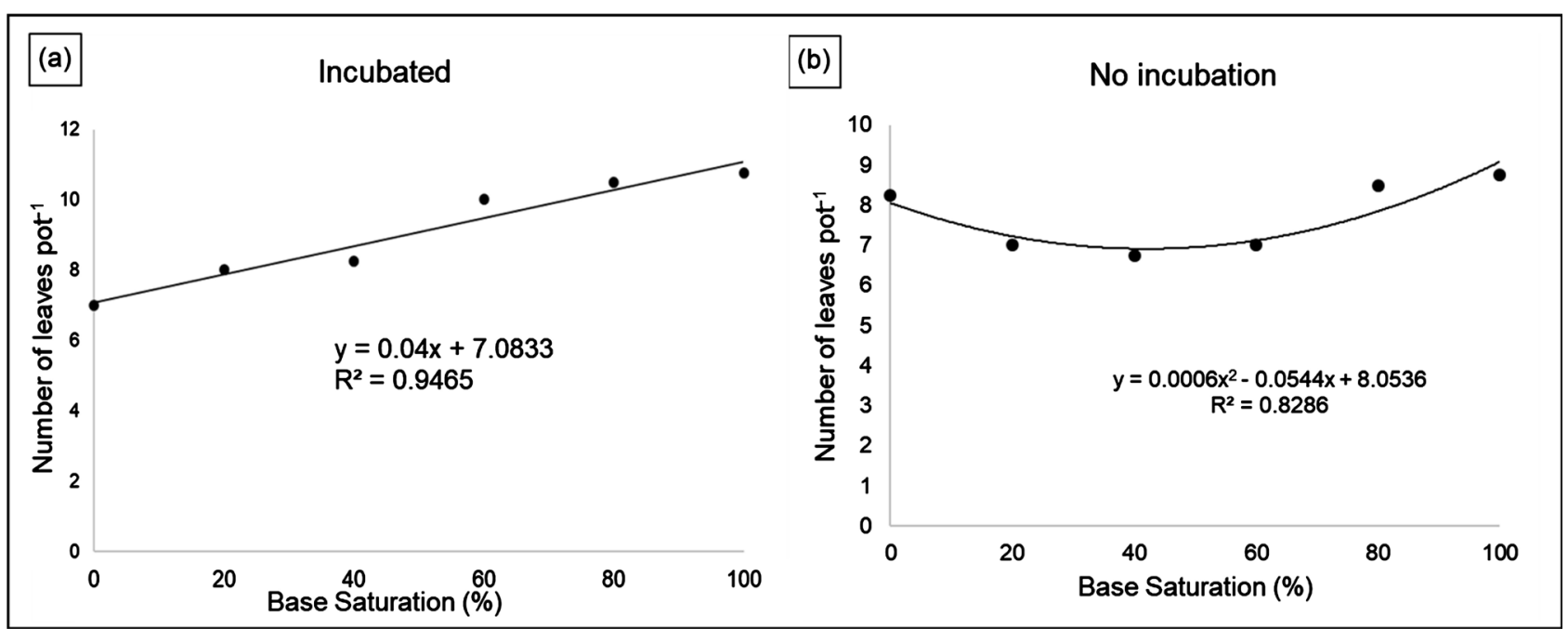

Figure 11. Number of leaves variation of Helianthus annuus L. cv. Folded Sungold as a function of the incubation times of 30 (a) and 0 days (b). 
At 60 DAS (Figure 13) there was only isolated effect for basal saturation levels, showing that, although the treatment no incubation presented slower foliage development, the crop closed the cycle without showing a significant difference in the number of leaves between the times of incubation.

In general, the vegetative development of the crop presented better results
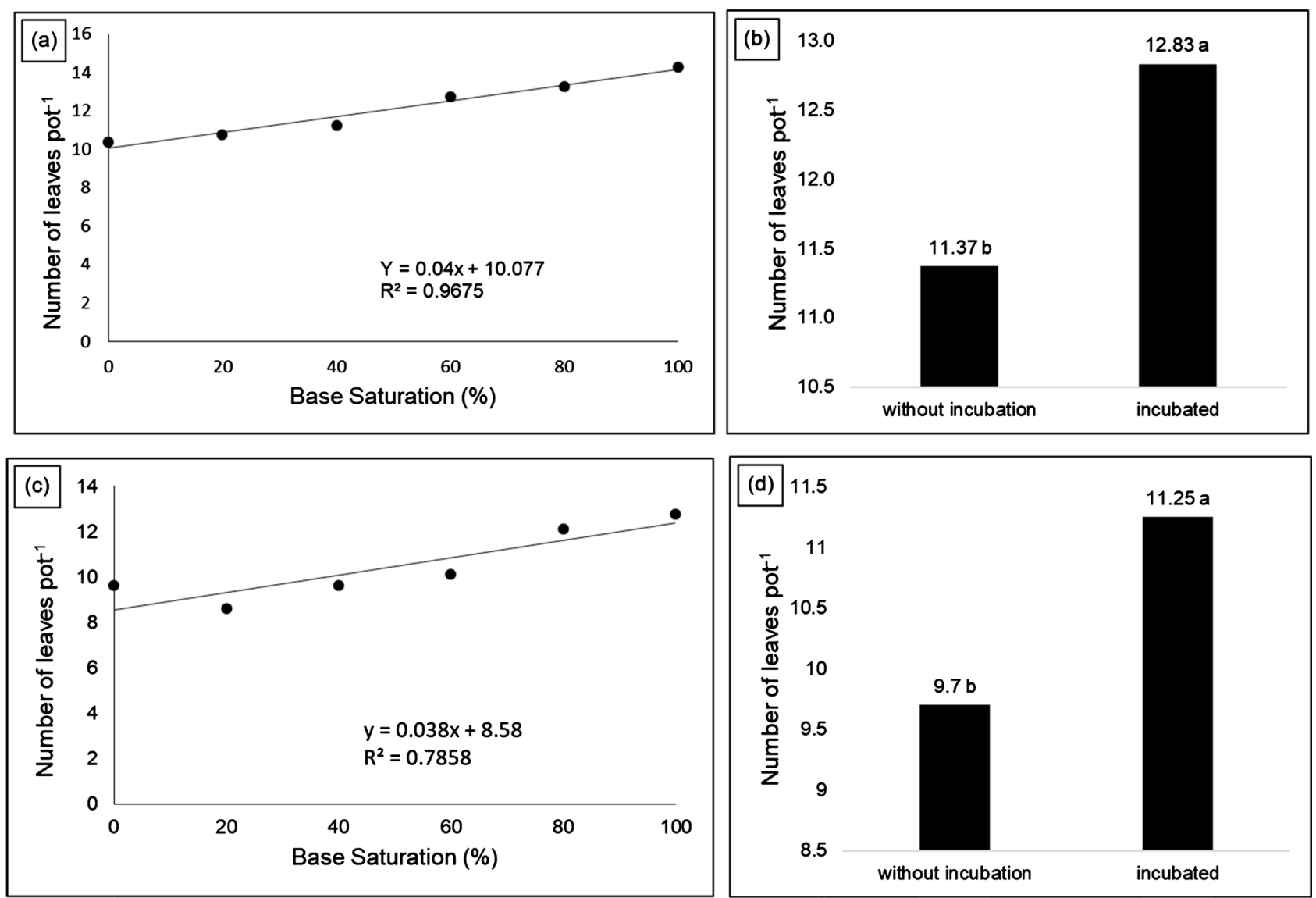

Figure 12. Number of Leaves of Helianthus annuus L. cv. Folded Sungold at 30 ((a) and (b)) and 45 ((c) and (d)) DAS with Isolated Basal Saturation Effect ((a) and (c)), isolated effect of days ((b) and (d)).

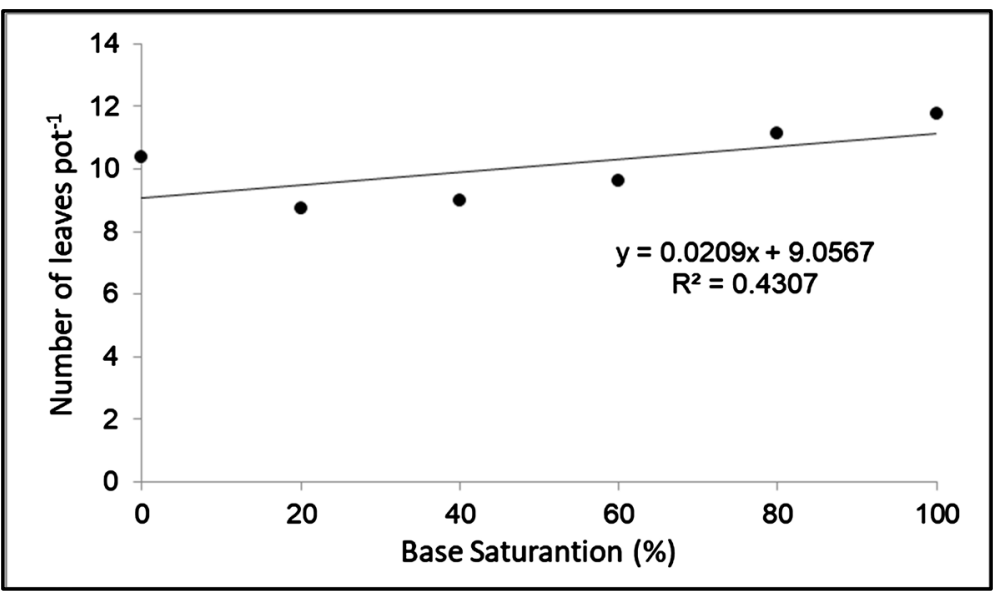

Figure 13. Effect isolated from the saturation levels by bases at 60 DAS in Helianthus annuus L. cv. Folded Sungold. 
when the $\mathrm{pH}$ was close to the ideal range of 6 , thus corroborating with the results of [21], who studied the production of ornamental sunflower using brackish water in a hydroponic system, monitored the $\mathrm{pH}$ and identified that the best vegetative development of the plant occurred when the $\mathrm{pH}$ was close to the ideal range for the crop.

\subsection{Stem Diameter}

At 15 and 30 days after emergence, the stem diameter showed isolated effect for base saturation (Figure 14(a) and Figure 14(c)) and days of incubation (Figure 14(b) and Figure 14(d)). Regardless of the incubation, at 15 and 45 days, the stem diameter was described by linear model, in which the largest diameter value obtained was at $100 \%$ saturation. Regardless of the saturations, the incubated treatments obtained higher values for this variable.

In the period of 45 and 60 days after emergence (Figure 15(a) and Figure 15(b)), there was significance only for basal saturation, both described by the linear model. Thus, the highest values found for the stem diameter were in the treatments with $100 \%$ of base saturation.

Reference [22], studying the effects of doses of dolomitic limestone on the
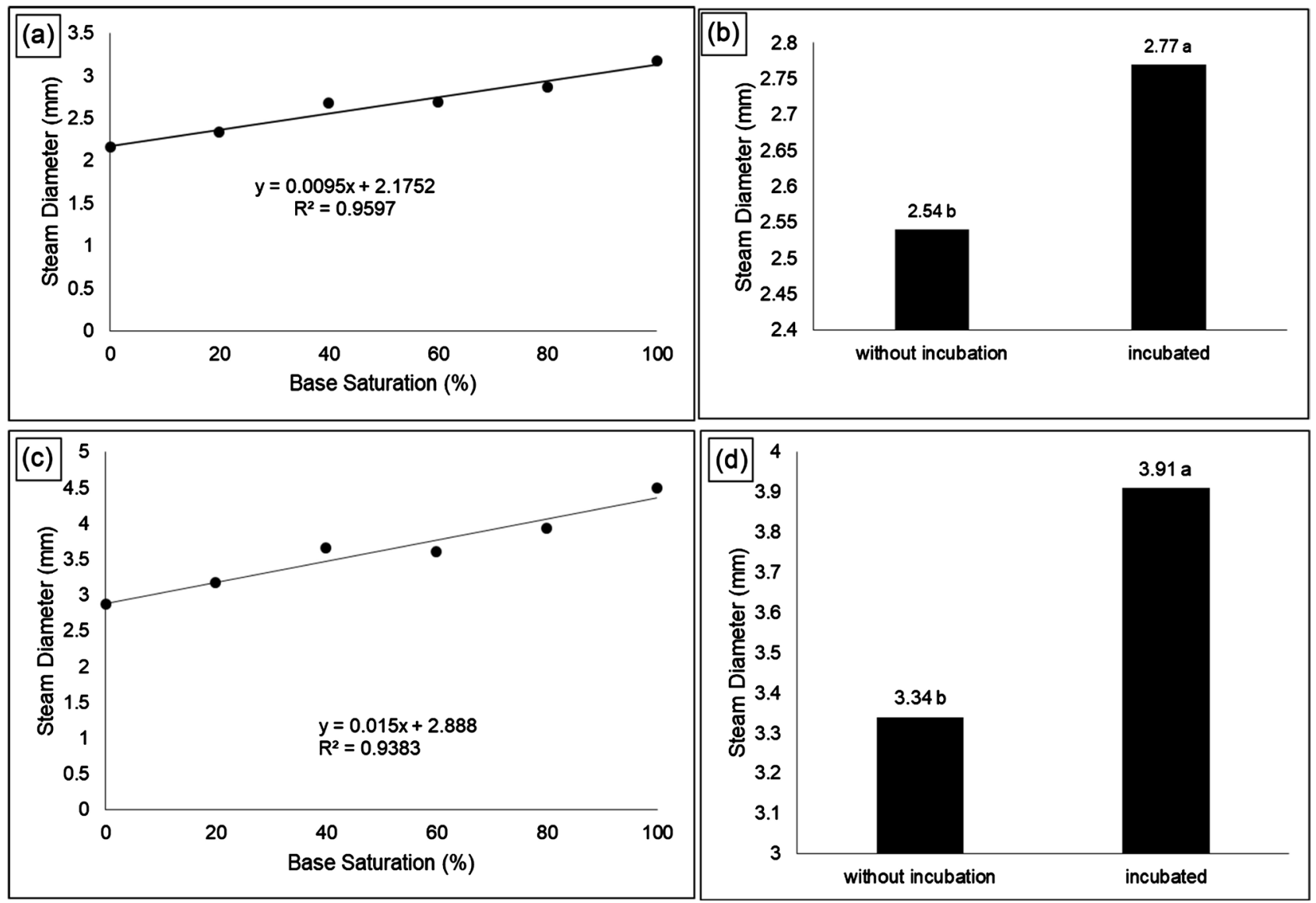

Figure 14. Stem diameter of Helianthus annuus L. cv. Folded Sungold at 15 ((a) and (b)) and 30 DAS ((c) and (d)) with Isolated Saturation by Bases ((a) and (c)), and isolated effect for incubation time ((b) and (d)). 


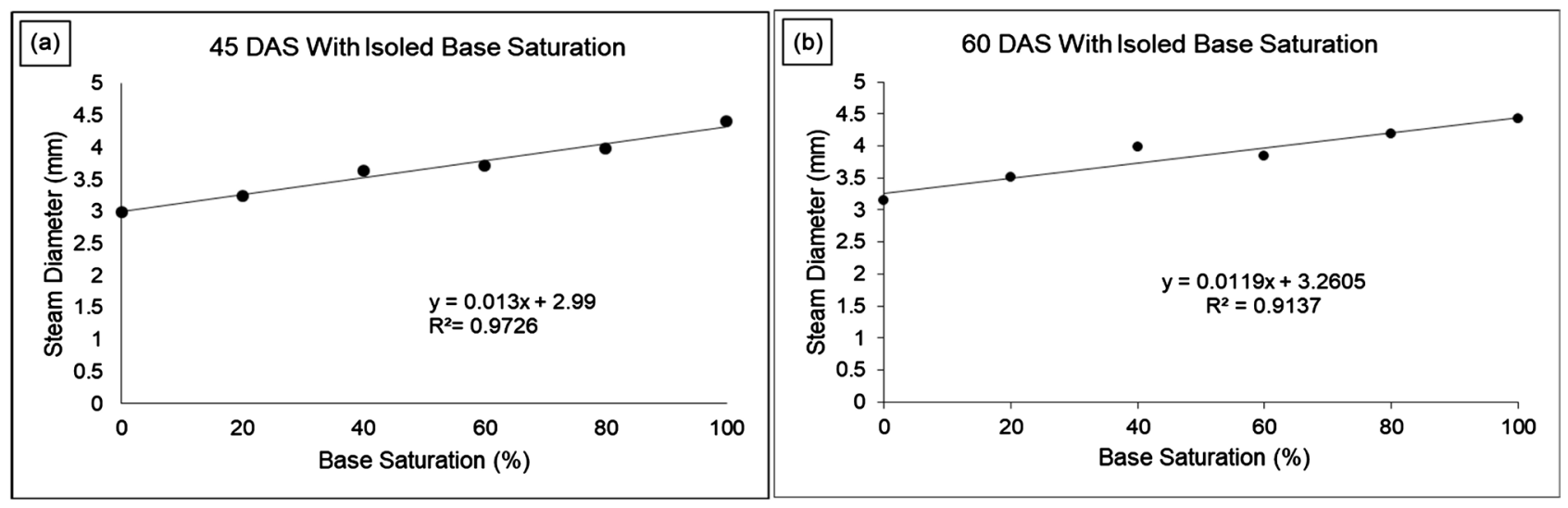

Figure 15. Stem diameter of Helianthus annuus L. cv. Folded Sungold at 45 (a) and 60 DAS (b) with Isolated Saturation by Bases.

growth of Heliconia psittacorum cv. Golden, observed that with the increase in base saturation there was a decrease in the diameter of the pseudostem, differing from the results obtained in the present work. In contrast, reference [23] studying the influence of base saturation on the growth and production of the cambre, observed that there was no significant effect on stem diameter as a function of base saturation levels.

These results show that in addition to the influence of $\mathrm{pH}$ on crop development, the phenological characteristics of the plants are influenced by their genetic potential [24], allowing different crops to have their development influenced in different ways to a certain condition nutritional.

\subsection{Diameter of the Buttons and Chapters}

The first flowers begin to emerge from 40 DAS. The diameter of the floral buds at 30 DAS (Figure 16) responded to the linear regression model alone as a function of base saturation levels.

At 45 DAS, in addition to responding to the linear regression model alone as a function of base saturation levels (Figure 17(a)), the incubation time was significant (Figure 17(b)). The isolated effect of the incubation time was due to the flowering process that began 5 days before the evaluation, indicating that the treatments no incubation showed slower floral development.

\subsection{Fresh and Dry Mass of Aerial Part}

The fresh shoot mass responded to the linear regression model alone as a function of base saturation levels (Figure 18). This shows that the higher the saturation level, the greater the development and growth of the plants. The results are closely related to the $\mathrm{pH}$ values identified at the time of planting, which varied from 5.0 to 5.9 in the incubated treatment, corresponding to the levels of 40 and $100 \%$ saturation, respectively; and from 4.6 to 5.6 in the no incubation treatment at 40 and $100 \%$ levels. Thus, since the ideal $\mathrm{pH}$ range for obtaining a higher degree of nutrient availability is between 6.0 and 7.0 [16], it was not possible to reach a point of maximum fresh mass accumulation. 


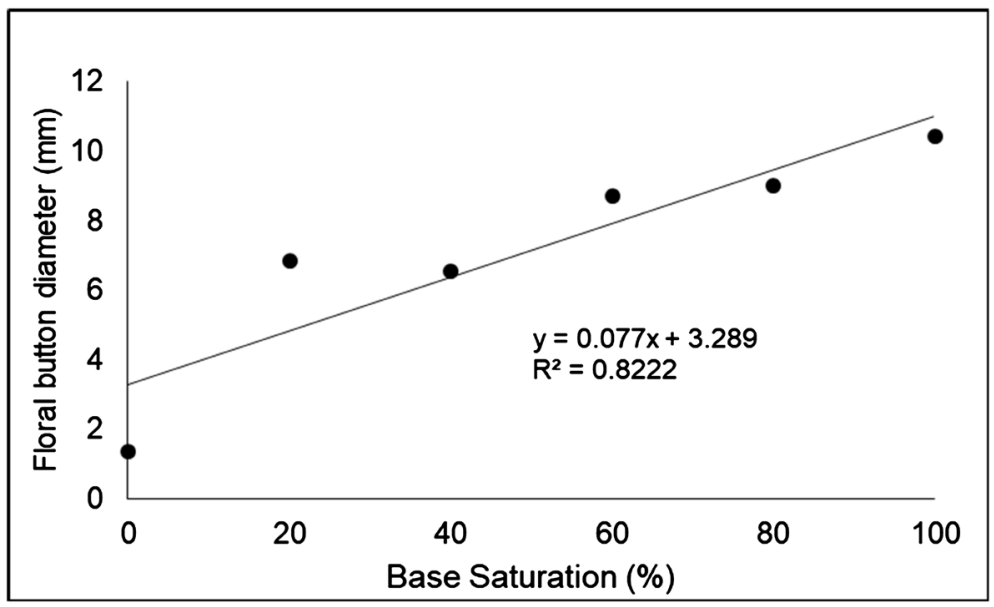

Figure 16. Floral Button Diameter of Helianthus annuus L. cv. Folded Sungold at 30 DAS (A).
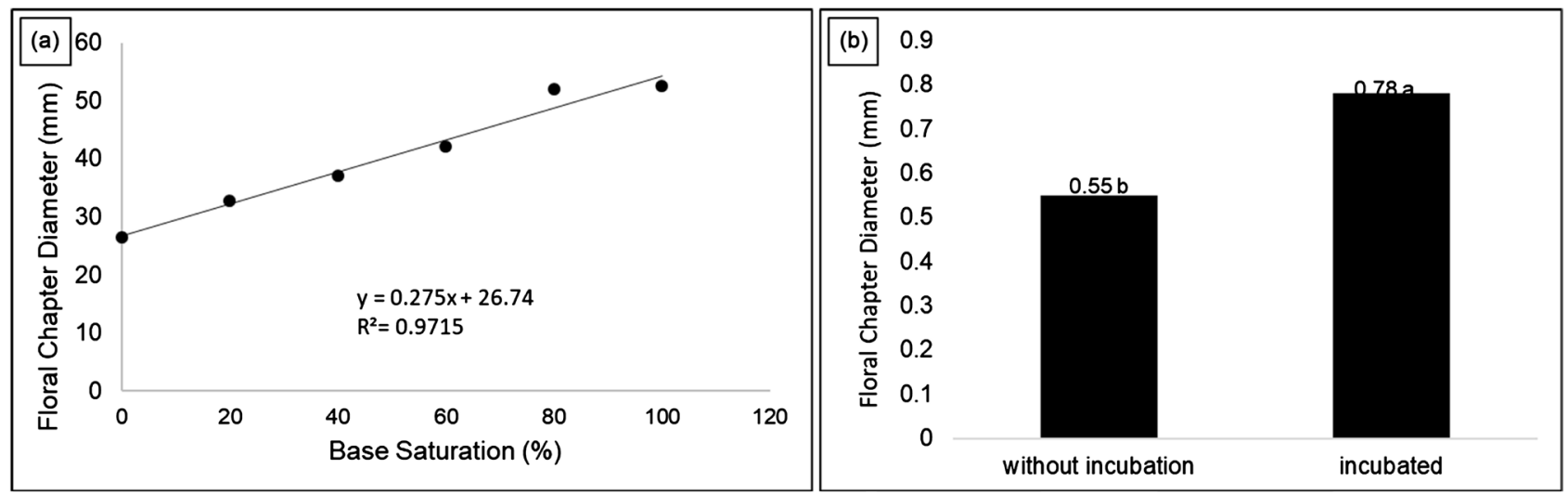

Figure 17. Diameter of floral chapters of Helianthus annuus L. cv. Folded Sungold at 45 DAS as a function of saturation (a), and isolated effect for incubation time (b).

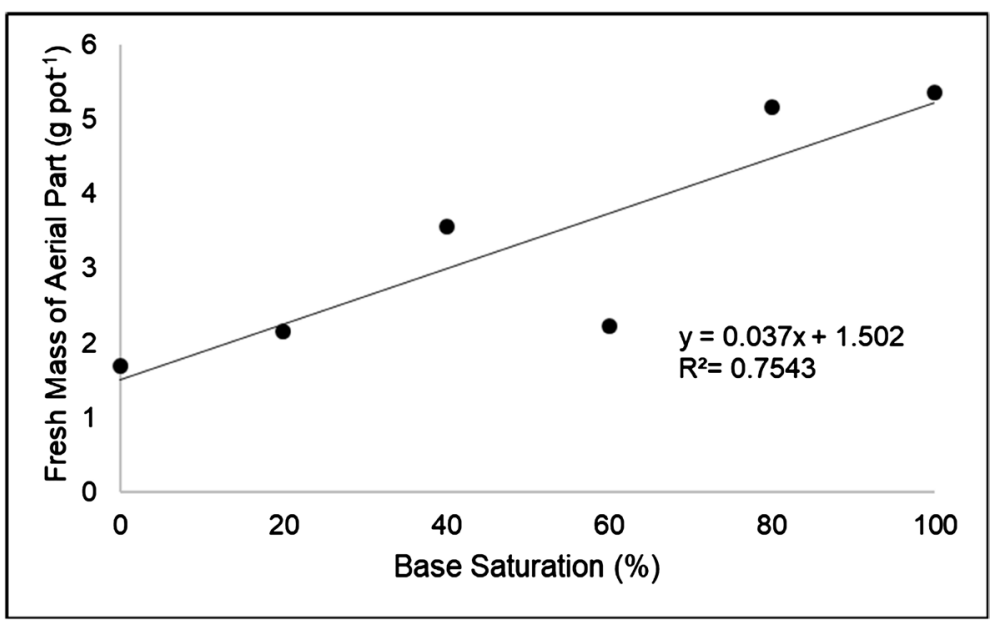

Figure 18. Weight (g) of fresh shoot mass of Helianthus annuus L. cv. Folded Sungold.

For the aerial part dry mass, besides the isolated response as a function of the saturation levels by bases (Figure 19(a)), an isolated effect was obtained for the incubation time (Figure 19(b)). The significant difference between the incu- 
bated and no incubation treatments emphasizes the importance of the incubation time of the limestone to occur with the soil reaction, and thus provide the necessary conditions for the cultivation and development of the plants. Incubation of the soil with limestone for 30 days, generally provided better conditions for nutrient absorption, which resulted in a higher shoot dry mass.

\subsection{Fresh and Dry Mass of Floral Chapters}

There was a significant effect at $1 \%$ probability of error, for the fresh and dry mass of the floral chapters. The linear model was the one that best described these variables, where the highest values for fresh mass and dry mass of the chapters were obtained in the treatments with $100 \%$ of base saturation.

The increase of the fresh mass and, consequently, dry mass of the chapters in function of the increase of the saturation by bases verified in Figure 20, can be explained by the fact that the treatments with level of $100 \%$ saturation by bases were those that obtained $\mathrm{pH}$ closer to the ideal culture. With this, there was a greater availability of nutrients to the plants, allowing a better development of the flower, as well as other phenological characteristics.

Reference [25] observed a decrease in the fresh mass of gladiolus horns as a
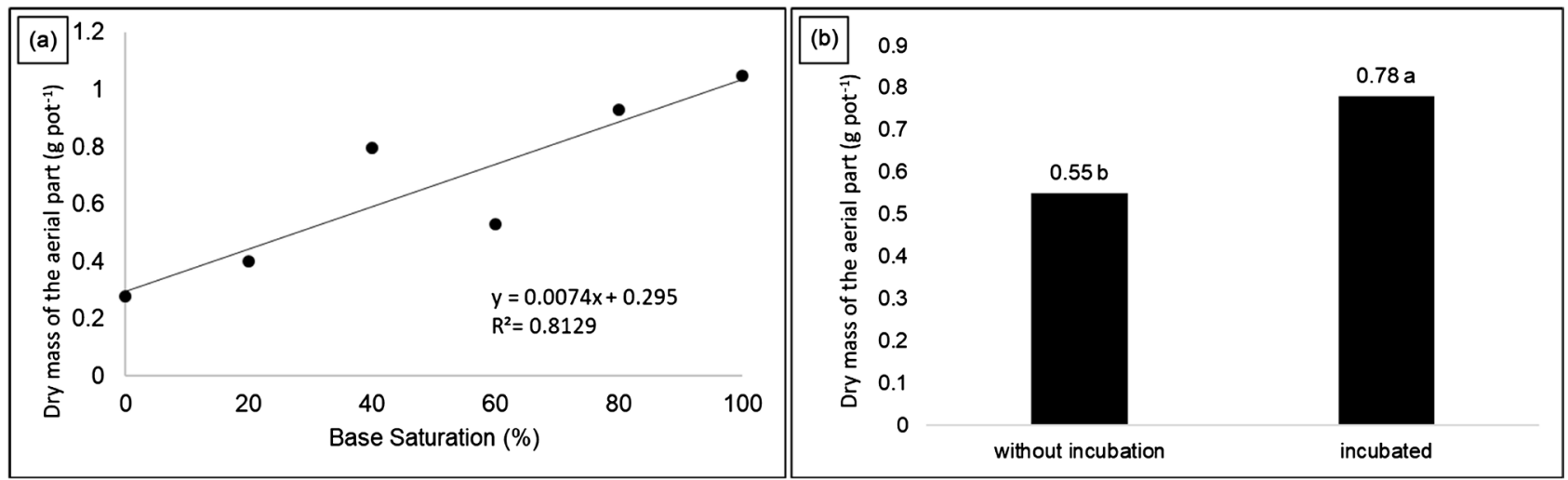

Figure 19. Weight (g) of the aerial shoot dry mass of Helianthus annuus L. cv. Folded Sungold as a function of saturation levels (a) and incubation time (b).
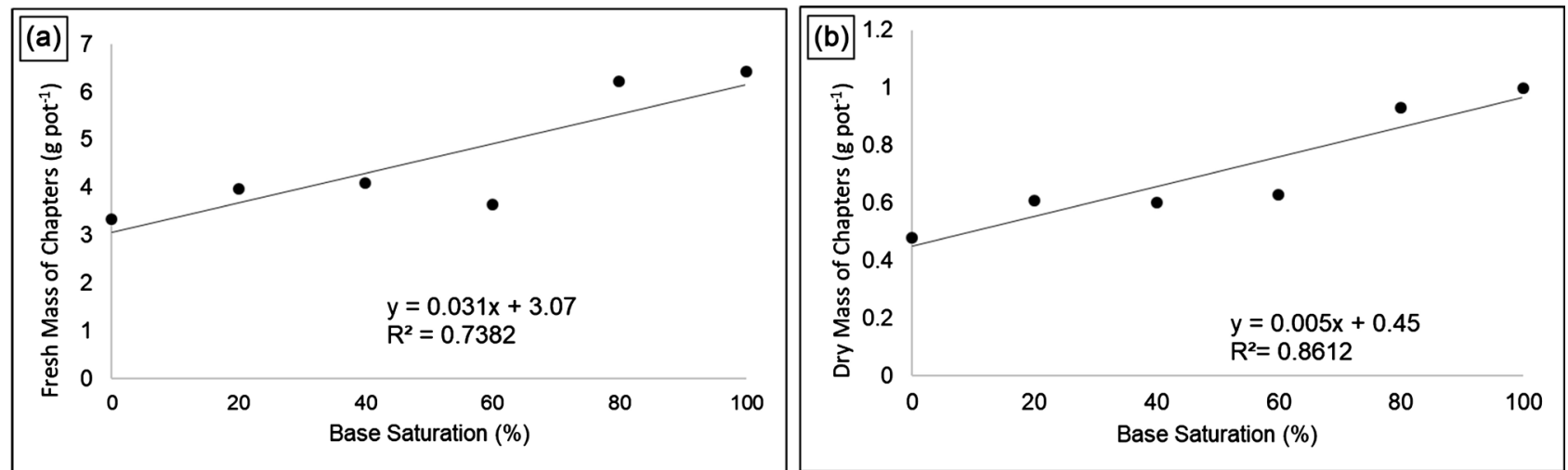

Figure 20. Fresh (a) and dry (b) mass of floral chapters of Helianthus annuus L. cv. Folded Sungold in response to base saturation levels and incubation days. 
function of limestone and potassium doses, differing from the results found in the present study.

\subsection{Volume and Dry Mass of Root}

The dry mass of the root (Figure 21(a)) and root volume (Figure 21(b)) of the dwarf sunflower responded to the linear regression model alone as a function of saturation levels per base. In Figure 22 it is possible visually to perceive the difference between the treatments.

The sunflower is a plant susceptible to soil acidity, and when subjected to these conditions the development of the root system is affected [26] thus causing the dry mass of the roots and their volume to be reduced.

Treatments with base saturation levels lower than those recommended in the literature $(0,20 \%$ and $40 \%)$ presented a root system with few and thick branches, differing from treatments $(60 \%, 80 \%$ and $100 \%)$, where the main root had a larger volume of branches. The reference [7], when evaluating sunflower behavior in relation to soil acidity, found an underdeveloped root system with bending of the main root, as well as fine roots when submitted to the acid environment.

The reference [27], working with liming on the development of the guava root

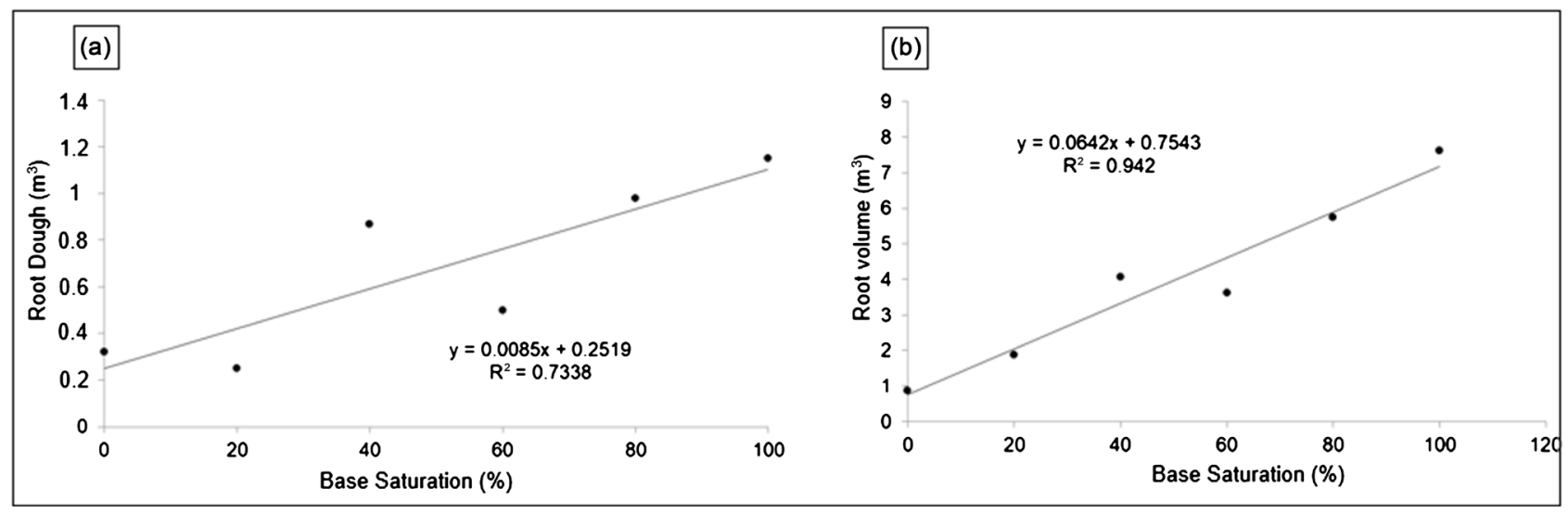

Figure 21. Root dry mass (a) and volume (b) of Helianthus annuus L. cv. Folded Sungold in response to base saturation levels and days of incubation.
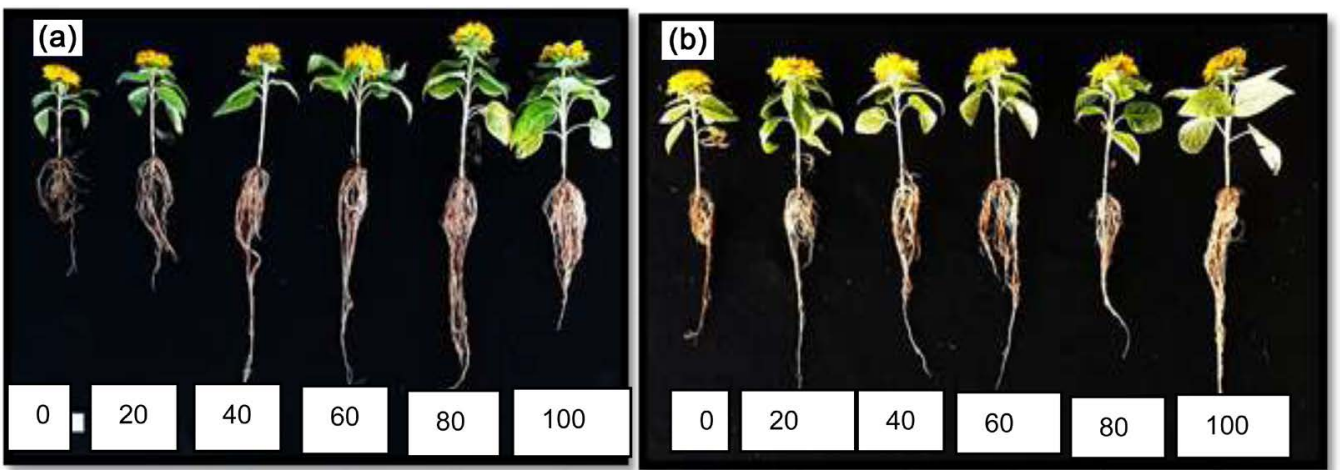

Figure 22. Root development of Helianthus annuus L. cv. Folded Sungold at 0, 20\%, 40\%, 60\%, 80\% and 100\% base saturation in incubated and no incubation (b) treatments. 

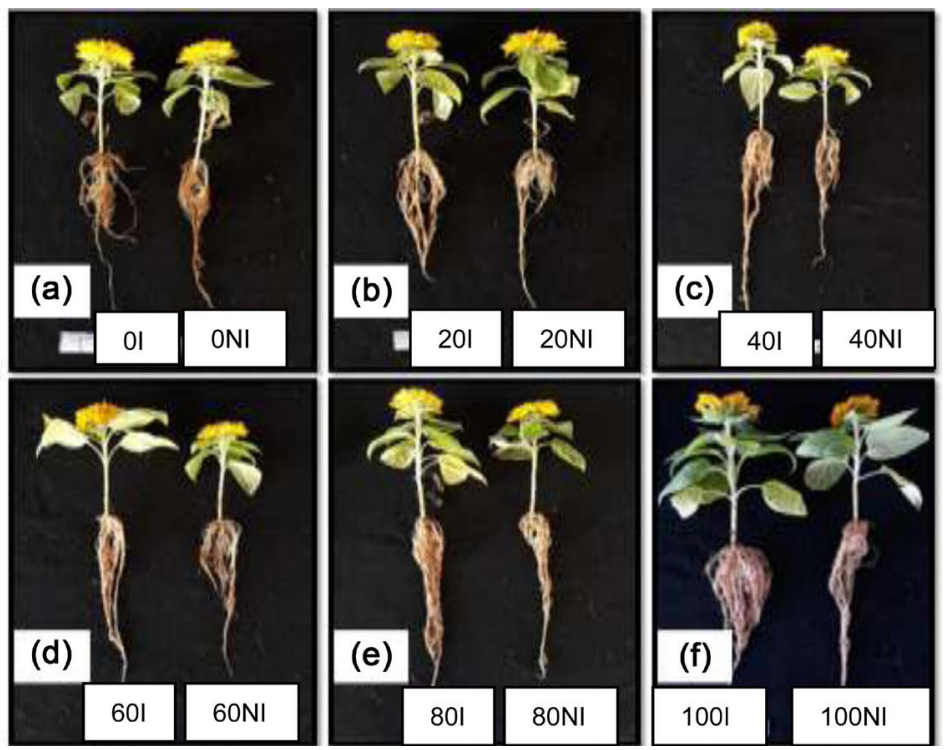

Figure 23. Comparison of root development of Helianthus annuus L. cv. Folded Sungold between treatments with incubated (I) and no incubation (NI) soil at doses 0 (a), 20 (b), 40 (c), 60 (d), 80 (e), and 100\% (f) base saturation.

system, concluded that the application of limestone linearly increases the root mass of the guava tree, being justified by the increase of Ca content in the soil, which caused greater absorption of this roots, reflecting the dry matter accumulation of the roots. The relationship between $\mathrm{Ca}$ content in roots and root mass reveals the beneficial effect of $\mathrm{Ca}$ on the root development of plants [28]. The importance of $\mathrm{Ca}$ to plants is due to the fact that about $60 \%$ of cellular $\mathrm{Ca}$ is present in the cell wall [29].

In Figure 23, root development at each dose was compared between incubated (I) and no incubated (NI) soil treatments: 0 incubated and 0 no incubated (Figure 23(a)), 20 incubated and 20 no incubated (Figure 23(b)), 40 incubated and 40 no incubated (Figure 23(c)), 60 incubated and 60 no incubated (Figure 23(d)), 80 incubated and 80 no incubated (Figure 23(e)), and 100 incubated and 100 no incubated (Figure 23(f)). The flowers are conditioned in the respective sequence: Treatment with soil incubated on the left, and without incubating on the right.

\section{Conclusions}

The levels of base saturation and the incubation times of limestone influenced the development of the dwarf sunflower.

The $\mathrm{pH}$ of the soil in the treatment no incubation was inferior to the treatment with incubation at the time of planting and harvest.

The best vegetative development was in the treatment with the saturation by bases in $100 \%$ with the soil incubated.

Basal saturation levels of $80 \%$ and $100 \%$, in the treatment with incubated soil, provided higher quality of inflorescence for commercialization purposes. 


\section{Conflicts of Interest}

The authors declare no conflicts of interest regarding the publication of this paper.

\section{References}

[1] Torres, D. (2015) Análise prospectiva para o setor atacadista de flores e plantas ornamentais no Brasil e suas tecnologias da informação e comunicação. MSc. Dissertação, Universidade Federal do Rio Grande do Sul, Porto Alegre.

[2] Serviço Brasileiro de Apoio às Micro e Pequenas Empresas Sebrae (2015) Flores e plantas ornamentais do Brasil. Volume 2, série estudos mercadológicos. Brasília.

[3] Tombolato, A.F.C., Uzzo, R.P., Junqueira, A.H., Peetz, M.S., Stancato, G.C. and Alexandre, M.A.V. (2010) Bulbosas ornamentais no Brasil. Revista Brasileira de Horticultura Ornamental, 16, 127-138. https://doi.org/10.14295/rbho.v16i2.553

[4] Zobiole, L.H.S., Castro, C., Oliveira, F.A. and Oliveira Junior, A. (2010) Marcha de absorção de macronutrientes na cultura do girassol. Revista Brasileira de Ciência do Solo, 34, 425-433. https://doi.org/10.1590/S0100-06832010000200016

[5] Oliveira, M.F. and Castiglioni, V.B.R. (2003) Girassol Colorido para o Brasil. Embrapa-CNPSo, Londrina.

[6] Empresa Brasileira de Pesquisa Agropecuária Embrapa (2019) Bioma Cerrado: Solos.

http://www.agencia.cnptia.embrapa.br/Agencia16/AG01/arvore/AG01_96_1011200 5101956.html

[7] Ungaro, M.R.G., Ouaggio, J.A., Gallo, P.B., Dechen, S.C.F., Lombardi Neto, F. and Castro, O.M. (1985) Comportamento do girassol em relação a acidez do solo. Bragantia, 44, 41-48. https://doi.org/10.1590/S0006-87051985000100004

[8] Cruz, C.A.F., Paiva, H.N., Gomes, K.C.O. and Guerrero, C.R.A. (2004) Efeito de diferentes níveis de saturação por bases no desenvolvimento e qualidade de mudas de ipê-roxo (Tabebuia impetiginosa (Mart.) Standley). Scientia Forestalis, 66, 100-107.

[9] Vieira, C. and Weber, O. (2017) Saturação por Bases no Crescimento e na Nutrição de Mudas de Ipê-Amarelo. Floresta e Ambiente, 24, 1-10. https://doi.org/10.1590/2179-8087.001916

[10] Alvares, C.A., Stape, J.L., Sentelhas, P.C., De Moraes, G., Leonardo, J. and Sparovek, G. (2013) Köppen's Climate Classification Map for Brazil. Meteorologische Zeitschrift, 22, 711-728. https://doi.org/10.1127/0941-2948/2013/0507

[11] Empresa Brasileira de Pesquisa Agropecuária Embrapa (2018) Sistema brasileiro de classificação de solos. 5nd Edition, Embrapa-SPI, Rio de Janeiro.

[12] Empresa Brasileira de Pesquisa Agropecuária (2017) Manual de métodos de análise de solo. 3rd Edition, Revista e ampliada. Embrapa, Brasília, 565 p.

[13] Sousa, D.M.G. and Lobato, E. (2004) Cerrado Correção do solo e adubação. Embrapa Informação Técnológica, Brasilia.

[14] Bonfim-Silva, E.M., Silva, T.J.A., Cabral, C.E.A., Kroth, B.E. and Rezende, D. (2011) Desenvolvimento inicial de gramíneas submetidas ao estresse hídrico. Revista Caatinga, 24, 180-186.

[15] Ferreira, D.F. (2011) Sisvar: A Computer Statistical Analysis System. Ciência e Agrotecnologia, 35, 1039-1042. https://doi.org/10.1590/S1413-70542011000600001 
[16] Malavolta, E. (1980) Elementos de nutrição mineral de plantas. Ceres, Piracicaba, $251 \mathrm{p}$.

[17] Nascimento, W.A., Pereira, K.S., Santos, P.L.S. and Santos, C.H.B. (2012) Efeitos de Diferentes Concentrações de Alúminio no Desenvolvimento Inicial de Plantas de Girassol. Centro Científico Conhecer, 8, 748-756.

[18] Hortenstine, C.C. and Fiskell, J.G.A. (1961) Effect of Aluminum on Sunflower Growth and Uptake of Boron and Calcium from Nutrient Solution. Soil Science Society of America Proceedings, 25, 304-307. https://doi.org/10.2136/sssaj1961.03615995002500040022x

[19] Blamey, F.P.C. (1975) Amelioration of an Acid Avalon Medium Sandy Loam and Effects on the Growth of Sunflowers (Helianthus annuus L.). Crop Production, 4, 75-79.

[20] Blamey, F.P.C. and Nathanson, K. (1978) Relationships between Aluminum Toxicity and Sunflower Yields on an Avalon Medium Loam. Sunflower News, 2, 6-12.

[21] Maciel, M.A.M., Pinto, A.C. and Veiga, V.E. (2002) Plantas medicinais: A necessidade de estudos multidisciplinares. Química Nova, 23, 429-438.

https://doi.org/10.1590/S0100-40422002000300016

[22] Souza, G.O., Viégas, I.J.M. and Frazão, D.A.C. (2009) Crescimento de Heliconia psittacorum cv. Golden torch em função de doses de calcário dolomítico. Revista Ciências Agrárias, 52, 49-59.

[23] Janegitz, M.C., Souza-Schlick, G.D., Tropaldi, L. and Cardoso, S.M. (2010) Influência da saturação por bases no crescimento e produção de cambre. Cultivando o Saber, 3, 175-182.

[24] Higaki, T., Imamura, J.S. and Paull, R.E. (1992) N, P and K Rates and Leaf Tissue Standards for Optimum Anthurium andraeanum Flower Production. Hortscience, 27, 909-912. https://doi.org/10.21273/HORTSCI.27.8.909

[25] Bratti, E.F., Rosa, Y.B.C.J., Silva, E.F., Rosa Júnior, E.J., Zárate, N.A.H., Bíscaro, G.A. and Rosa, D.B.C.J. (2012) Cultivo de gladíolos em função das doses de calcário e potássio. Horticultura Brasileira, 30, 397-402. https://doi.org/10.1590/S0102-05362012000300007

[26] Castro, C., Castiglioni, V.B.R., Balla, A., Leite, R.M.V.B.C., Karam, D., Mello, C.H., Guedes, L.C.A. and Farias, J.R.B. (1996) A cultura do Girassol. Embrapa-CNPSo, Londrina, $38 \mathrm{p}$.

[27] Prado, R.M. (2004) Calagem na nutrição de cálcio e no desenvolvimento do sistema radicular da goiabeira. Pesquisa agropecuária brasileira, 39, 1007-1012. https://doi.org/10.1590/S0100-204X2004001000008

[28] Ritchey, K.D., Silva, J.E. and Costa, U.F. (1982) Calcium Deficiency in Clayey B Horizons of Savanna Oxisols. Soil Science, 133, 378-382. https://doi.org/10.1097/00010694-198206000-00007

[29] Tobias, R.B., Conway, W.S., Sams, C.E., Gross, K.C. and Whitaker, B.D. (1992) Cell Wall Composition of Calcium-Treated Apples Inoculated with Botrytis cinerea. Phytochemistry, 32, 35-39. https://doi.org/10.1016/0031-9422(92)80102-K 